\title{
PENINGKATAN KETERAMPILAN MENULIS PARAGRAF DESKRIPTIF DENGAN MENGGUNAKAN MODEL EXAMPLES NON-EXAMPLES
}

\author{
Muhammad Zikri Wiguna ${ }^{1}$, Ramadhan Kusuma Yudha ${ }^{2}$ \\ 1,2 Program Studi Pendidikan Bahasa dan Sastra Indonesia IKIP PGRI Pontianak \\ Jalan Ampera Nomor 88 Pontianak \\ email korespondensi: zeskarind.zack@gmail.com
}

\begin{abstract}
Abstrak
Penelitian ini dilatarbelakangi keinginan peneliti untuk meningkatkan keterampilan menulis paragraf deskriptif dengan menggunakan model Examples Non Examples pada siswa kelas X IPS 3 MAN 1 Pontianak. Adapun tujuan penelitian ini adalah (1) mendeskripsikan proses pelaksanaan pembelajaran keterampilan menulis paragraf deskriptif dengan menggunakan model Examples Non Examples pada siswa kelas X IPS 3 MAN 1 Pontianak, (2) mendeskripsikan proses pelaksanaan pembelajaran keterampilan menulis paragraf deskriptif dengan menggunakan model Examples Non Examples pada siswa kelas X IPS 3 MAN 1 Pontianak.Penelitian ini dilakukan dengan metode deskriptif dengan bentuk penelitian penelitian tindakan kelas (classroom action research). Adapun teknik pengumpul data yang digunakan dalam penelitian ini adalah teknik observasi, wawancara, dan tes. Alat pengumpul data yang digunakan adalah pedoman observasi, panduan wawancara, dan soal tes. Teknik analisis data yang digunakan adalah teknik deskriptif komperatif dan teknik analisis kritis.Berdasarkan hasil penelitian, dapat disimpulkan hal-hal berikut. Hasil observasi siswa siklus I persentase keseluruhannya adalah $66,40 \%$ sedangkan hasil observasi siswa siklus II persentase $78,20 \%$. Hasil observasi siswa pada siklus I dan siklus II ini ada peningkatan, meningkat 11,8\%. Selanjutnya, dari hasil penelitian dapat diketahui bahwa terdapat peningkatan dari prasiklus ke siklus I sebesar 13,38, peningkatan dari siklus I ke siklus II sebesar 6,15 dan peningkatan dari prasiklus ke siklus II sebesar 19,53.
\end{abstract}

Kata Kunci : keterampilan menulis, metode Examples Non Examples, menulis paragraf deskriptif

\begin{abstract}
The study was backed by the researcher wishes to enhance the descriptive paragraph writing skills by using the model Examples Non Examples on students of class X IPS 3 MAN 1 Pontianak. As for the purpose of this study is to (1) describe the process of implementation of the learning descriptive paragraph writing skills by using the model Examples Non Examples at the grade 1 MAN X IPS 3 Pontianak, (2) describe the implementation process learning the skills to write a descriptive paragraph using the model Examples Non Examples at the grade 1 MANX IPS 3 Pontianak. This research was conducted with descriptive method with the class action research research (classroom action Research). As for data-collecting techniques used in this research is the technique of observation, interviews, and tests. Data collecting tool used is manual observation, interview guides, and the question of the test. Data analysis techniques used are descriptive techniques komperatif and critical analysis techniques. Based on the results of the research, it can be concluded the following. Observations of students cycle I the percentage of overall was $66.40 \%$ whereas observations of students cycle II percentage of $78.20 \%$. Observation results of students in cycle I and cycle II is increased, an increase of $11.8 \%$. Furthermore, the results of the research can be known that there is increased from prasiklus to the cycle I of 13.38, an increase from cycle to cycle I II of 6.15 and improvement of prasiklus to cycle II amounted to 19.53.

Keywords: Writting Skill, Example non Example Methode, Descriptive Writting Paragraph
\end{abstract}




\section{PENDAHULUAN}

Pendidikan merupakan faktor penting untuk perkembangan kemajuan suatu bangsa. Pendidikan itu sendiri bertujuan untuk mengembangkan kemampuan serta meningkatkan mutu kehidupan dan martabat manusia sehingga membentuk individu menjadi manusia seutuhnya. Pendidikan sangat erat kaitannya dengan sumber daya manusia karena pendidikan merupakan kunci utama untukmenciptakan sumber daya manusia yang berkualitas.

Model Examples Non Examples merupakan salah satu pendekatan Group investigation dalam pembelajaran kooperatif yang dirancang untuk mempengaruhi pola interaksi siswa dan meningkatkan perolehan hasil akademik. Tipe pembelajaran ini dimaksudkan sebagai alternatif terhadap model pembelajaran kelas tradisional dan menghendaki siswa saling membantu dalam kelompok kecil dan lebih dicirikan oleh penghargaan kooperatif daripada individu. ( Ibrahim, 2000 :3).

Menurut Yadi (2004:11) model pembelajaran kooperatif tipe example non example adalah:“Tipe pembelajaran yang mengaktifkan siswa dengan cara guru menempelkan contoh gambar-gambar yang sesuai dengan tujuan pembelajaran dan gambar lain yang relevan dengan tujuan pembelajaran, kemudian siswa disuruh untuk menganalisisnya dan mendiskusikan hasil analisisnya sehingga siswa dapat membuat konsep yang esensial."

Gambar juga mempunyai peranan penting dalam proses belajar mengajar, yakni untuk mempermudah dan membantu siswa dalam membangkitkan imajinasinya dalam belajar. Selain itu dengan mengggunakan gambar siswa dapat melatih mencari dan memilih urutan yang logis sesuai dengan materi yang diajarkan. Dengan demikian dalam Model Pembelajaran Examples Non Examples tercakup teori belajar konstruktivisme.

Examples non Examples merupakan model pembelajaran dengan mempersiapkan gambar, diagram atau table sesuai materi bahan ajar dan kompetensi. Sajian gambar ditempel atau memakai OHP, dengan petunjuk guru siswa mencermati gambar, lalu diskusi kelompok tentang sajian gambar tadi, 
persentasi hasil kelompok, bimbingan penyimpulan, evaluasi, dan refleksi (Suyatno, $2009: 73$ )

Menulis merupakan upaya mengekspresikan yang dilihat, dialami, dirasakan, dan dipikirkan ke dalam bahasa tulis, informasi-informasi dan ide-ide tersebut dituangkan dalam bentuk tulisan (Hakim, 2005: 15).

Keterampilan menulis adalah salah satu kegiatan yang harus dihadapi siswa dalam proses pembelajaran, terutama untuk mata pelajaran bahasa dan sastra Indonesia. Tarigan (2008:3) menulis merupakan suatu keterampilan berbahasa yang dipergunakan untuk berkomunikasi secara tidak langsung, tidak secara tatap muka dengan orang lain. Melaluikegiatan menulis diharapkan siswa dapat menuangkan ide-ide atau gagasan baik yang bersifat ilmiah maupun imajinatif.

Sebagai keterampilan yang bersifat produktif dan ekspresif, keterampilan menulis sering dikatakan sebagai keterampilan yang paling kompleks. Keterampilan menulis digunakan untuk mencatat, merekam, meyakinkan, melaporkan, menginformasikan, dan mempengaruhi pembaca. Maksud dan tujuan seperti itu hanya dapat dicapai dengan baik oleh para pembelajar yang dapat menyusun, merangkai pikiran, dan mengemukakan secara tertulis dengan jelas, lancar, dan komunikatif. Dalam kegiatan menulis, seseorang harus terampil memanfaatkan struktur bahasa dan kosa kata. Dalam pengertian, kejelasan tulisan bergantung kepada pikiran, organisasi, pemakaian, dan pemilihan kata, dan struktur kalimat.

Sehubungan dengan itu, Keraf (1995: 93) menyatakan bahwa dekripsi atau pemerian merupakan sebuah bentuk tulisan yang bertalian dengan usaha para penulis untuk memberikan perincian-perincian objek yang sedang dibicarakan. Selanjutnya Slavin dan Chotimah (2007 : 1) dijelaskan bahwa examples non examples adalah model pembelajaran yang menggunakan contoh-contoh. Contohcontoh dapat diperoleh dari kasus atau gambar yang relevan dengan Kompetensi Dasar.

Konsep model pembelajaran ini pada umumnya dipelajari melalui dua cara. Paling banyak konsep yang kita pelajari di luar sekolah melalui pengamatan dan 
juga dipelajari melalui definisi konsep itu sendiri. Example Non Examples adalah taktik yang dapat digunakan untuk mengajarkan definisi konsep. Taktik ini bertujuan untuk mempersiapkan siswa secara cepat dengan menggunakan 2 hal yang terdiri dari Example dan non-Examples dari suatu definisi konsep yang ada, dan meminta siswa untuk mengklasifikasikan keduanya sesuai dengan konsep yang ada. Example memberikan gambaran akan sesuatu yang menjadi contoh akan suatu materi yang sedang dibahas, sedangkan non-Examples memberikan gambaran akan sesuatu yang bukanlah contoh dari suatu materi yang sedang dibahas. Dengan memusatkan perhatian siswa terhadap example dan non-example diharapkan akan dapat mendorong siswa untuk menuju pemahaman yang lebih dalam mengenai materi yang ada. (Hamzah, 2005:113).

Example Non Example dianggap perlu dilakukan karena suatu definisi konsep adalah suatu konsep yang diketahui secara primer hanya dari segi definisinya daripada dari sifat fisiknya. Dengan memusatkan perhatian siswa terhadap example dan non-example diharapkan akan dapat mendorong siswa untuk menuju pemahaman yang lebih dalam mengenai materi yang ada.

Sadiman dalam Rahyu (2011) "media” berasal dari kata “medium” yang berarti perantara atau pengantar dalam menyampaikan pesan komunikasi. Media pembelajaran adalah segala sesuatu yang dapat digunakan untuk menyalurkan pesan (bahan pembelajaran), sehingga dapat merangsang perhatian, minat, pikiran, dan perasaan siswa dalam kegiatan belajar untuk mencapai tujuan belajar. Oleh karena proses pembelajaran merupakan proses komunikasi dan berlangsung dalam suatu sistem, maka media pembelajaran menempati posisi yang cukup penting sebagai salah satu komponen sistem pembelajaran. Media salah satu sumber belajar yang dapat merangsang siswa belajar. Dalam proses belajar mengajar harus terjadi komunikasi antara guru sebagai sumber pesan dengan siswa sebagai penerima pesan. Menurut Wijaya dalam Astuty (2012) media berperan sebagai perangsang belajar dan dapat menumbuhkan motivasi belajar sehingga siswa tidak menjadi bosan dalam meraih tujuan tujuan belajar. Dalam pembelajaran media memiliki fungsi antara lain : mengatasi hambatan proses komunikasi, sikap pasif siswa dalam belajar dan mengatasi keterbatasan fisik siswa (Murtini , 2011). 
Pengajaran menulis dikenal dengan 5 bentuk paragraf yaitu paragraf naratif, paragraf deskriptif, paragraf ekspostif, argumentasi dan persuasi. Paragraf deskriptif adalah paragraf yang mengambarkan atau melukiskan suatu objek dengan terperinci terhadap objek yang dibicarakan tersebut. Pengajaran menulis ditujukan agar siswa mampu memahami dan dapat mengomunikasikan ide atau gagasan dalam bentuk tulisan.

Berdasarkan kenyataannya, dalam proses belajar mengajar siswa sering mengalami kesulitan dalam memahami materi. Hal ini terjadi karena proses pembelajaran yang dilaksanakan hanya berpusat pada guru dan siswa hanya sebagai objek penerima informasi. Dalam upaya memudahkan proses pembelajaran tersebut, guru harus dapat memilih model pembelajaran yang sesuai agar dapat menciptakan situasi dan kondisi kelas yang kondusif.

Berdasarkan dari uraian di atas, tampaknya perlu dilakukan suatu kegiatan yang mampu meningkatkan keterampilan Menulis Paragraf Deskriptif menggunakan model Example non Example untuk siswa-siswi X IPS 3 MAN I Pontianak. Agar mengkaji lebih dalam guna memperoleh jawaban dan informasi yang objektif. Dengan kondisi siswa di kelas MAN 1 Pontianak yang kurang aktif saat proses belajar mengajar berlangsung dan kurangnya motivasi dalam belajar, maka peneliti merasa bahwa model Example Non Examples di kelas X IPS 3 MAN 1 Pontianak dapat meningkatkan hasil belajar siswa.

\section{METODE}

Metode penelitian adalah suatu cara yang digunakan dalam pemecahan masalah penelitian. Hikmat (2011:35) mengatakan bahwa metode penelitian adalah tindakan yang harus dilakukan oleh seorang peneliti jika menginginkan penelitiannya dapat menjawab masalah dan menemukan kebenaran. Sedangkan Sugiyono (2013:3) mengatakan metode penelitian adalah cara ilmiah untuk mendapatkan data dengan tujuan dan kegunaan tertentu. Dari kedua pendapat tersebut maka dapat disimpulkan bahwa metode penelitian adalah cara ilmiah yang digunakan untuk menemukan kebenaran dan memecahkan masalah untuk mencapai tujuan dalam suatu penelitian.Sehubungan dengan metode yang digunakan adalah metode deskriptif, Mahmud (2011:100) menyatakan bahwa, penelitian deskriptif 
adalah suatu penelitian yang diupayakan untuk mengamati permasalahan secara sistematis dan akurat mengenai fakta dan objek tertentu.

Berdasarkan beberapa pendapat ahli di atas, dapat disimpulkan bahwa metode deskriptif adalah suatu pemecahan masalah dalam penelitian dengancara pengumpulan data yang berdasarkan pada kenyataan atau kondisi yang sebenarnya.Alasan mengambil metode deskriptif karena penelitian ini dilaksanakan dengantujuan untuk memecahkan masalah yang diselidiki melihat dan mengetahui model pembelajaran Examples Non Examples pada keterampilan menulis paragraf deskripsi.

\section{HASIL DAN PEMBAHASAN}

\section{A. Deskripsi Kondisi Awal (Pratindakan)}

Peneliti melakukan survei awal dulu sebelum dilakukan penelitian tindakan kelas (PTK) untuk melihat proses pembelajaran secara langsung. Survei awal ini dimaksudkan untuk mengetahui kondisi awal pembelajaran keterampilan menulis paragraf deskriptif. Kondisi awal ini menjadi acuan untuk menentukan tindakan apa saja yang dilakukan pada pembelajaran dalam siklus selanjutnya.

Kegiatan pratindakan adalah kegiatan yang dilakukan untuk mengawali penelitian tindakan kelas. Kegiatan pratindakan dilakukan oleh guru yaitu dari perencanaan, pelaksanaan dan hasil. Perencanaan yang dilakukan berupa membuat rencana pelaksanaan pembelajaran (RPP) yang diamati oleh peneliti terhadap proses pembelajaran sebagai berikut. Guru membuka pelajaran dengan mengucap salam, Guru melakukan apersiasi, untuk memotivasi minat belajar para siswa, guru mengondisikan kelas dengan mengabsen siswa siapa yang tidak masuk, kemudian melakukan apresiasi dengan siswa tentang pengertian paragraf deskriptif, Guru menjelaskan materi tentang menulis paragraf deskriptif, Guru menyuruh siswa membuat paragraf deskriptif secara individu. Nilai yang dihasilkan siswa belum maksimal yaitu rata-rata 60,37, ketuntasan klasikalnya $44 \%$.

Setelah mengamati proses pembelajaran, peneliti mewawancarai guru mata pelajaran Bahasa Indonesia kelas X IPS 3 MAN 1 Pontianak dengan bantuan panduan wawancara yang sudah dibuat sebelumnya. Darihasil wawancara dapat diketahui bahwa guru mengalami kendala di bagian pemilihan metode, karena 
biasanya hanya menggunakan metode konvensional berupa ceramah, diskusi, permodelan, dan penugasan.

Simpulan yang dapat ditarik dari hasil wawancara dengan guru dan pengamatan yang dilakukan oleh peneliti adalah bahwa permasalahan yang dihadapi guru dalam pembelajaran keterampilan menulis paragraf deskriptif adalah kurang menggunakan metode yang variatif, sehingga kurang dapat membangkitkan motivasi siswa dalam belajar.

\section{B. Deskripsi Pelaksanaan Penelitian}

Peneliti melakukan kegiatan Penelitian Tindakan Kelas melalui dua siklus, dilaksanakan secara berkelanjutan dari siklus I kemudian dilanjutkan sampai siklus II. Setiapsiklus meliputi empat tahap kegiatan yaitu perencanaan, tindakan,observasi, dan refleksi. Hasil penelitian ini bertujuan untuk meningkatkan keterampilan menulis paragraf deskriptif dengan menggunakan model Examples Non Examples pada siswa kelas X IPS 3 MAN 1 Pontianak.

Pelaksanaan penelitian dimulai dengan langkah-langkah peneliti datang ke sekolah menyerahkan surat izin penelitian kepada kepala sekolah, kemudian kepala sekolah memberikan wewenang dan menyerahkan urusan kepada guru bidang studi bahasa Indonesia kelas X. Mengadakan observasi dan menerapkan tindakan dengan kesepakatan guru sebagai pelaksana (pelaku)dan peneliti sebagai observer (pengamat). Peneliti melakukan wawancara pada guru dan siswa, tentang peningkatan pembelajaran menulis paragraf deskriptif dan model Examples Non Examples.

Siklus I Perencanaan Pada tahap perencanaan peneliti bekerjasama dengan guru bahasa Indonesia mendiskusikan Rencana Pelaksanaan Pembelajaran (RPP) siklus I, berlokasi di ruangan guru di MAN 1 Pontianak. Berdasarkan diskusi yang dilakukan peneliti bersama guru dan berdasarkan hasil observasi, guru dan peneliti merencanakan tentang rencana pembelajaran yang akan dilaksanakan di kelas, menyusun Rencana Pelaksanaan Pembelajaran (RPP), mempersiapkan lembar observasi pelaksanaan pembelajaran, soal unjuk kerja atau tes untuk siswa, dan penilaian soal tes. 
Pelaksanaan tindakan kelas ini dilaksanakan dengan 2 kali pertemuan per siklus, berlokasi di ruangan kelas X IPS 3. Langkah-langkah pelaksanaan tindakan yang dilakukan dalam proses pembelajaran pada siklus I antara lain sebagai berikut. Pelaksanaan tindakan kelas ini dilaksanakan dengan 2 kali pertemuan per siklus, berlokasi di ruangan kelas X IPS 3. Langkah-langkah pelaksanaan tindakan yang dilakukan dalam proses pembelajaran pada siklus I antara lain sebagai berikut.

Pertemuan pertama Pelaksanaan pembelajaran ini meliputi 3 kegiatan pembelajaran, yaitu pendahuluan, kegiatan inti, dan penutup. Pendahuluan Pendahuluan adalah langkah awal yang dilakukan guru dalam proses pembelajaran. Hal-hal yang dilakukan guru pada bagian pendahuluan ini antara lain sebagai berikut. Memusatkan perhatian siswa terlebih dahulu dengan cara mempersiapkan kelas, mengucapkan salam, dan mengabsen siswa. Guru menyampaikan tujuan pembelajaran. Melakukan apersepsi dengan caramemberikan pertanyaan. Kegiatan inti, Kegiatan inti merupakan kegiatan pokok yang akan dilakukan dalam proses pembelajaran. Hal-hal yang dilakukanpada kegiatan inti adalah sebagai berikut. Guru melakukan tanya jawab dengan siswa mengenai paragraf deskriptif. Gurumenayangkan gambar-gambar melalui media pembelajaran. Guru membagi kelompok secara acak, tiap kelompok terdiri dari 2-3 siswa. Guru memberikan petunjuk dan memberikan kesempatan kepada siswa untuk memperhatikan atau menganalisis gambar. Guru menugaskan siswa secara berkelompok untuk menulis paragraf deskriptif berdasarkan tema keindahan alam. Masing-masing kelompok berdiskusi untuk menulis paragraf deskriptif berdasarkan gambar-gambar yang sudah ditayangkan. Guru meminta perwakilan siswa untuk membaca hasil kerja kelompok dan tiap kelompok membaca hasil diskusinya didepan kelas. Kelompok lain memberi tanggapan atau komentar mengenai hasil kerja kelompok temannya.

Berdasarkan komentar atau hasil diskusi siswa, guru menjelaskan materi sesuai tujuan yang ingin dicapai. Penutup Kegiatan penutup merupakan kegiatan akhir, sebelum proses pembelajaran selesai. Pada kegiatan penutup guru melakukan beberapa hal sebagai berikut. Guru menanyakan kesulitan siswa dalam menulis paragraf deskriptif dengan menggunakan media gambar. Guru memberikan 
dorongan kepada siswa untuk terus belajar menulis paragraf deskriptif. Guru bersama siswa menyimpulkan pembelajaran hari ini.

Pertemuan kedua Tahap kegiatan yang sama pada pertemuan pertamayaitu pendahuluan, kegiatan inti, dan penutup. Pendahuluan Kegiatan yang dilakukan guru pada pendahuluan ini masih sama dengan kegiatan pendahuluan pada pertemuan pertama, yaitu Memusatkan perhatian siswa terlebih dahulu dengan cara mempersiapkan kelas, mengucapkan salam, dan mengabsen siswa. Guru menyampaikan tujuan pembelajaran Melakukan apersepsi dengan caramemberikan pertanyaan. Kegiatan inti Adapun hal-hal yang dilakukan pada kegiatan inti pertemuan kedua ini adalah sebagai berikut. Guru meminta siswa berkelompok, sesuai pada pertemuan pertama. Guru meminta perwakilan siswa untuk melanjutkan membaca hasil kerja kelompok bagi kelompok yang belum membaca hasil pekerjaannya.

Kelompok lain memberi tanggapan atau komentar mengenai hasil kerja kelompok temannya. Secara individu siswa memperhatikan atau menganalisis gambar yang sudah ditayangkan. Tiap siswa saling menilai hasil kerja temanya Guru memberi memberi penjelasan ulang tentang bagaimana menulis paragraf deskriptif Guru memberi kesempatan kepada siswa untuk bertanya terkait pada materi menulis paragraf deskriptif Guru memberikan penguatan pada siswa. Penutup Pada kegiatan penutup ini guru melakukan hal-hal sebagai berikut. Guru menanyakan kesulitan siswa dalam menulis paragraf deskriptif dengan menggunakan media gambar. Guru memberikan dorongan kepada siswa untuk terus belajar menulis paragraf deskriptif. Guru bersama siswa menyimpulkan pembelajaran hari ini.

Berdasarkan observasi guru berusaha melaksanakan pembelajaran sesuai dengan langkah-langkah pembelajaran yang telah direncanakan sebelumnya. Observasi pelaksanaan pembelajaran oleh guru ini terdiri dari 15 komponen kegiatan pembelajaran. Persentase hasil observasi pelaksanaan pembelajaran siklus I yang dilakukan guru adalah sebesar 73,33\%, dengan kategori cukup.

Hasil kerja siswa secara berkelompok di siklus I dengan nilai rata-rata 68,43 atau 68 dikategorikan cukup baik dari 32 orang siswa yang dibagi menjadi 16 
kelompok. Siswa yang tuntas atau mampu mencapai Kriteria Ketuntasan Minimum (KKM) atau yang memperoleh nilai 75 dan 75 ke atas berjumlah 14 orang dengan persentase sebesar $43,75 \%$. Sedangkan siswa yang tidak tuntas adalah 18 orang dengan persentase sebesar $56,25 \%$.

Refleksi digunakan untuk menentukan dan menyimpulkan apakah pelaksanaan tindakan pada siklus I masih perlu dilanjutkan atau tidak.Berdasarkan data yang diperoleh dari hasil observasi proses pelaksanaan pembelajaran pada siklus I, terdapat peningkatan keterampilan menulis paragraf deskriptif. Namun peneliti merasa bahwa penerapan model Examples Non Examples belum terlalu berpengaruh pada keterampilan menulis paragraf deskriptif. Terbukti dengan masih ada beberapa siswa yang belum memenuhi indikator kinerja yang diharapkan peneliti.

Ketidakpuasan peneliti terhadap hasil observasi proses pembelajaran pada siklus I itu, kemudian peneliti sampaikan pada guru mata pelajaran yang bersangkutan. Setelah melihat hasil unjuk kerja siswa pada siklus I, maka guru dan peneliti sepakat untuk melanjutkan penelitian ini pada siklus II dengan materi pembelajaran dan model pembelajaran yang sama.

Siklus II Pada tahap perencanaan ini, peneliti kembali bekerjasama dengan guru bahasa Indonesia mendiskusikan Rencana Pelaksanaan Pembelajaran (RPP) siklus II, berlokasi di ruangan guru di MAN 1 Pontianak. Berdasarkan diskusi yang dilakukan peneliti bersama guru, guru dan peneliti merencanakan tentang rencana pembelajaran yang akan dilaksanakan di kelas, menyusun Rencana Pelaksanaan Pembelajaran (RPP) yang baru untuk siklus II, mempersiapkan lembar observasi pelaksanaan pembelajaran baru, soal unjuk kerja atau tes untuk siswa dan wawancara yang baru.Pelaksanaan tindakan kelas pada siklus II ini masih dilaksanakan dengan 2 kali pertemuan, berlokasi di ruangan kelas X IPS 3 . Langkah-langkah pelaksanaan tindakan yang dilakukan dalam proses pembelajaran pada siklus II antara lain sebagai berikut.

Pertemuan pertama siklus II dilaksanakan dalam waktu 80 menit atau 2 jam pelajaran. Pelaksanaan pembelajaran ini sama dengan siklus I, yaitu meliputi 3 kegiatan pembelajaran, yaitu pendahuluan, kegiatan inti, dan penutup. Pendahuluan 
adalah langkah awal yang dilakukan guru dalam proses pembelajaran. Hal-hal yang dilakukan guru pada bagian pendahuluan ini sama dengan pendahuluan yang dilakukan pada siklus I. Memusatkan perhatian siswa terlebih dahulu dengan cara mempersiapkan kelas, mengucapkan salam, dan mengabsen siswa. Guru menyampaikan tujuan pembelajaran. Melakukan apersepsi dengan caramemberikan pertanyaan.

Kegiatan inti merupakan kegiatan pokok yang akan dilakukan dalam proses pembelajaran. Hal-hal yang dilakukanpada kegiatan inti adalah sebagai berikut. Guru melakukan tanya jawab dengan siswa mengenai paragraf deskriptif. Guru menayangkan gambar-gambar melalui media pembelajaran. Guru membagi kelompok secara acak, tiap kelompok terdiri dari 2-3 siswa. Guru memberikan petunjuk dan memberikan kesempatan kepada siswa untuk memperhatikan atau menganalisis gambar. Guru menugaskan siswa secara berkelompok untuk menulis paragraf deskriptif berdasarkan tema keadaan ruangan. Masing-masing kelompok berdiskusi untuk menulis paragraf Deskriptif berdasarkan gambar-gambar yang sudah ditayangkan. Guru meminta perwakilan siswa untuk membaca hasil kerja kelompok dan tiap kelompok membaca hasil diskusinya didepan kelas. Kelompok lain memberi tanggapan atau komentar mengenai hasil kerja kelompok temannya.

Berdasarkan komentar atau hasil diskusi siswa, guru menjelaskan materi sesuai tujuan yang ingin dicapai.

Kegiatan penutup merupakan kegiatan akhir, sebelum proses pembelajaran selesai. Pada kegiatan penutup guru melakukan beberapa hal sebagai berikut. Guru menanyakan kesulitan siswa dalam menulis paragraf deskriptif dengan menggunakan media gambar. Guru memberikan dorongan kepada siswa untuk terus belajar menulis paragraf deskriptif. Guru bersama siswa menyimpulkan pembelajaran hari ini. Pertemuan kedua siklus II dilaksanakan dalam waktu 80 menit atau 2 jam pelajaran. Tahap pelaksanaan pembelajaran ini sama dengan pelaksanaan pembelajaran pada pertemuan pertama, yaitu pendahuluan, kegiatan inti, dan penutup. Kegiatan yang dilakukan guru pada pendahuluan ini masih sama dengan kegiatan pendahuluan pada pertemuan pertama. Memusatkan perhatian siswa terlebih dahulu dengan cara mempersiapkan kelas, mengucapkan salam, dan 
mengabsen siswa. Guru menyampaikan tujuan pembelajaran. Melakukan apersepsi dengan caramemberikan pertanyaan. Adapun hal-hal yang dilakukan pada kegiatan inti pertemuan kedua ini adalah sebagai berikut. Guru meminta siswa berkelompok, sesuai pada pertemuan pertama. Guru meminta perwakilan siswa untuk melanjutkan membaca hasil kerja kelompok bagi kelompok yang belum membaca hasil pekerjaannya. Kelompok lain memberi tanggapan atau komentar mengenai hasil kerja kelompok temannya. Secara individu siswa memperhatikan atau menganalisis gambar yang sudah ditayangkan. Tiap siswa saling menilai hasil kerja temannya

Guru memberi memberi penjelasan ulang tentang bagaimana menulis paragraf deskriptif. Guru memberi kesempatan kepada siswa untuk bertanya terkait pada materi menulis paragraf deskriptif Guru memberikan penguatan pada siswa. Pada kegiatan penutup ini guru melakukan hal-hal sebagai berikut. Guru menanyakan kesulitan siswa dalam menulis paragraf deskriptif dengan menggunakan media gambar. Guru memberikan dorongan kepada siswa untuk terus belajar menulis paragraf deskriptif. Guru bersama siswa menyimpulkan pembelajaran hari ini.

Berdasarkan observasi siklus II guru berusaha melaksanakan pembelajaran sesuai dengan langkah-langkah pembelajaran yang telah direncanakan sebelumnya. Persentase hasil observasi pelaksanaan pembelajaran siklus II yang dilakukan guru adalah sebesar $85,33 \%$, dengan kategori sangat baik. Hasil kerja siswa secara berkelompok di siklus II dengan nilai rata-rata 79,43 atau 79 dikategorikan baik dari 32 orang siswa yang dibagi menjadi 16 kelompok. Siswa yang tuntas atau mampu mencapai Kriteria Ketuntasan Minimum (KKM) atau yang memperoleh nilai 75 dan 75 ke atas berjumlah 28 orang dengan persentase sebesar $87,5 \%$. Sedangkan siswa yang tidak tuntas adalah 4 orang dengan persentase sebesar $12,5 \%$.

Refleksi digunakan untuk menentukan dan menyimpulkan apakah pelaksanaan tindakan pada siklus II masih perlu dilanjutkan lagi ke siklus berikutnya atau tidak. Melihat data yang diperoleh dari hasil observasi proses pelaksanaan pembelajaran pada siklus II, terdapat peningkatan keterampilan 
menulis paragraf deskriptif dari siklus I ke siklus II. Dengan demikian peneliti bersama guru membuat kesepakatan untuk menghentikan penelitian tindakan kelas ini pada siklus II.

\section{SIMPULAN}

Berdasarkan analisis data dan hasil penelitian, maka dapat disimpulkan bahwa terdapat peningkatan keterampilan menulis paragraf deskriptif pada siswa kelas X IPS 3MAN 1 Pontianak dengan menggunakan model Examples Non Examples. Secara khusus dapat disimpulkan bahwa, sebagai berikut. Peningkatan hasil tes siswa juga diikuti dengan perubahan perilaku siswa kelas X IPS 3 MAN 1 Pontianak kearah yang positif setelah dilaksanakan pembelajaran menulis paragraf deskriptif dengan menggunakan model Examples Non Examples. Pada saat pembelajaran menulis paragraf deskriptif siklus I beberapa siswa aktif dalam mengikuti pembelajaran, akan tetapi masih banyak siswa yang cenderung pasif dan kurang memperhatikan penjelasan dari guru. Siswa juga masih senang berbicara dengan temannya. Pada saat pembelajaran menulis paragraf deskriptif pada siklus II perilaku siswa berubah. Siswa lebih semangat, antusias, dan bersungguh-sungguh mengikuti pembelajaran. Perilaku negatif siswa pada siklus I sudah dapat terkendali dan berubah menjadi perilaku positif pada siklus II. Hal ini tampak ketika siswa mendengarkan penjelasan dari guru, serta siswa merasa senang ketika menulis paragraf deskriptif sehingga siswa dapat mengumpulkan tepat pada waktu yang ditentukan guru.

Hasil observasi siswa siklus I persentase keseluruhannya adalah 66,40\% sedangkan hasil observasi siswa siklus II persentase 78,20\%. Hasil observasi siswa pada siklus I dan siklus II ini ada peningkatan, meningkat 11,8\%. Hasil dari penelitian menunjukan bahwa adanya peningkatan keterampilan menulis paragraf deskriptif siswa dengan menggunakan model Examples Non Examples. Peningkatan ini dapat dilihat dari hasil tes yang dilakukan pada siswa kelas X IPS 3 MAN 1 Pontianak yang meliputi tes siklus I dan tes siklus II. Hasil prasiklus menunjukkan rata-rata nilai yang dicapai siswa MAN 1 Pontianak sebesar 60,37 atau belum mencapai nilai batas ketuntasan yang telah ditetapkan oleh guru, hasil tes siklus I menunjukkan rata-rata nilai yang dicapai siswa sebesar 73,75 atau 
masuk kategori cukup baik, sedangkan pada siklus II rata-rata nilai yang dicapai adalah 79,90 termasuk kategori baik. Ini berarti terjadi peningkatan dari prasiklus ke siklus I sebesar 13,38, peningkatan dari siklus I ke siklus II sebesar 6,15 dan peningkatan dari prasiklus ke siklus II sebesar 19,53.

\section{UCAPAN TERIMA KASIH}

Terima kasih diucapkan kepada pihak mitra yakni siswa-siswi MAN I Pontianak serta dewan guru dan Kepala MAN I pontianak atas partisipasinya dan kerjasamanya, serta pihak IKIP PGRI Pontianak yang telah mendukung memberikan bantuan dana untuk kelancaran kegiatan pengabdian kepada masyarakat.

\section{DAFTAR PUSTAKA}

Astuty, N. 2012. Penerapan Model Pembelajaran Kooperatif Tipe Examples non Examples Dengan Menggunakan Alat Peraga Untuk Meningkatkan Hasil Belajar Siswa di Kelas VIII. Jurnal Exacta, 10 (1).

Hakim, M. Arief. 2005. Kiat Menulis Artikel di Media dari Pemula sampai Mahir. Bandung: Cendikia.

Hamzah B. Uno dan Nurdin, Muhammad, 2005. Belajar Dengan Pendekatan PAILKEM Jakarta: PT Bumi Aksara.

Hikmat.2011. Metode Penelitian Yogyakara: Graha Ilmu.

Keraf, Gorys. 1995. Eksposisi Komposisi Lanjutan II. Jakarta: Grasindo.

Mahmud. (2011). Metode Penelitian Pendidikan.Bandung: CV Pustaka Setia.

Murtini, S. 2011. Ketrampilan Menyimak Cerpen Melalui Media Kaset Audio Pada Siswa Kelas IX D SMP Negeri 1 Tegal Tahun 2010/2011. Pedagogik Jurnal Pendidikan Dasar dan Menengah. 5 (1): 97-104.

Ibrahim, Muslimin (2000). Pembelajaran Kooperatif. Surabaya: University Press.

Rahyu. 2011. Media Pembelajaran. http://skripsi-tesis karya ilmiah.blogspot.com2011/04/media pembelajaran.html

Rochyandi, Yadi. (2004). Model Pembelajaran Kooperatif. Surabaya: Masmedia Buana Pustaka. 
Sugiyono. (2013). Metode Penelitian Pendidikan (Pendekatan Kuantatif, Kualitatif, dan R\&D). Bandung : Alfabeta.

Suyatno. 2009. Menjelajah Pembelajaran Inovatif. Sidoarjo: Masmedia Buana Pustaka.

Slavin, dan Chotimah. 2007. Cooperative Learning Teori, Riset dan Praktik. Bandung: Nusa Media.

Tarigan, H.G. (2008). Menulis. Bandung: Angkasa Bandung. 